\title{
IL2RA Gene
}

National Cancer Institute

\section{Source}

National Cancer Institute. IL2RA Gene. NCI Thesaurus. Code C21563.

This gene plays a role in clathrin-independent endocytosis and immune functions. 